\title{
Design and static analysis of the Taizhou Yangtze River Bridge, China
}

$1 \quad$ Min Zhang MEng

Post-doctoral Candidate, Beijing Jiaotong University, Beijing, China

2 Tianbao Wan MEng

Deputy Chief Engineer, China Railway Major Bridge Reconnaissance \& Design Institute Co. Ltd, Wuhan, China
3 Yingliang Wang PhD, CEng, MICE

Deputy Chief Engineer, China Railway Major Bridge Reconnaissance and Design Institute Co. Ltd., Wuhan, China
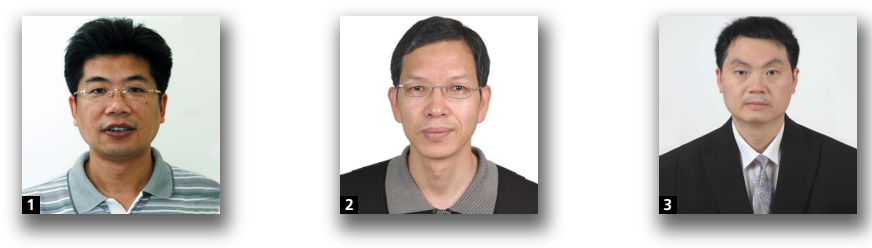

The Taizhou Yangtze River Bridge in China is a triple-pylon suspension bridge with double main spans of $1080 \mathrm{~m}$; it is the world's first triple-pylon suspension bridge with double main spans larger than $1000 \mathrm{~m}$. This paper presents the general design feature and innovation, global static analysis and construction of the main channel bridge, including the introduction of the general behaviour of a triple-pylon suspension bridge, the foundation and block of anchorages, foundation and shaft of pylons, steel box girder, main cable, cable band, main cable saddle, splay saddle, as well as the friction factor experiment between the main cable and main saddle.

\section{Notation \\ $F_{\text {Ed1 }}$ \\ $F_{\text {Ed2 }}$ \\ $K$ \\ $\alpha_{\mathrm{s}}$ \\ $\mu$}

There are many port engineering and ship anchorages around the bridge location. To reduce the impact of bridge construction on the environment, keep flood discharge to a minimum, maintain the sustainable development and facilitate navigation, the bridge adopted a triple-pylon suspension with double main spans and a main cable span arrangement of $390+1080+$ $1080+390 \mathrm{~m}$. The steel box girder is suspended in the double main spans. The solution reduces the obstacle to the water current and ensures the original width of the main channel. The conventional double-pylon suspension bridge has a main span twice that of the triple-pylon bridge. Compared with this, the triple-pylon suspension bridge halves the horizontal force of the main cable, so the amount of anchorage and main cable is reduced significantly. The bridge includes the northern approach bridge, Jiajiang Bridge, main channel bridge and southern approach bridge. In this paper, only the main channel bridge is described - the key part of the project.

\section{Design criteria}

The key design criteria adopted for the bridge include

carriage lanes: six lanes in the short-term and eight lanes in the long-term

bridge width: $33.0 \mathrm{~m}$ (excluding cable anchorage zone width)

design speed: $100 \mathrm{~km} / \mathrm{h}$ 
- live load standard: Chinese highway load class I

navigation clearance: the width and height of the navigational channel should not be less than $760 \mathrm{~m}$ and $50 \mathrm{~m}$, respectively

design wind speed: the average maximum wind speed within $10 \mathrm{~min}$ is $31.83 \mathrm{~m} / \mathrm{s}$ with 100 -year return period and $10 \mathrm{~m}$ above the mean sea level

- according to the site earthquake safety assessment report, which was completed by the seismic department of the Jiangsu Province, the ground surface horizontal acceleration is $0 \cdot 159 \mathrm{~g}$ and with a return period of 100 years and an exceedance probability of $10 \%$, and $0 \cdot 207 \mathrm{~g}$ with a return period of 100 years and an exceedance probability of $4 \%$, respectively

the ship collision force of the main pylon is $116 \mathrm{MN}$ and $58 \mathrm{MN}$ in the transverse and longitudinal direction, respectively.

\section{Design standards}

In accordance with the requirement of the client, the preliminary and detailed design of the permanent works were carried out following Chinese Specifications for Highway Steel Bridges (hereafter in short CSHSB). However, the steel orthotropic deck design of the highway bridge was not covered, so BS EN 1993-2 (CEN, 2005) and German national annex (DIN, 2003) were adopted in the bridge design for the supplement.

\section{Design of the main bridge}

\subsection{General design of main bridge}

Based on the construction conditions at the bridge site, both side pylons are set on the river bank, whereas the middle pylon is set in the middle of the river at a water depth about $18 \mathrm{~m}$ under ordinary water level. Both anchorages are designed on the bank. The main bridge is located on the straight line in plan. The main bridge is a steel box girder suspension bridge with double main spans of $1080 \mathrm{~m}$ (Figure 1); the main cable arrangement is $390+1080+1080+390 \mathrm{~m}$.

The ratio of cable sag to span is a key parameter of the general design of a large-span suspension bridge, which affects the structural rigidity, material quantities and the control point of main cable. It is determined by the balance of the global rigidity, dead load and construction cost. The ratio of cable sag to span was studied from $1 / 7$ to $1 / 13$. The static analysis result determines that, under live load, the slip resistance safety factor between the main cable and the main saddle increases with increasing of sag-tospan ratio, but the extent is very limited. In addition, the deflection of the main girder increases very rapidly with the increasing sagto-span ratio. With the increasing ratio of sag-to-span, the critical flutter wind velocity increases, but the extent is very limited. Allowing for the static and dynamic structural behaviour and the quantities of construction materials, the sag-to-span ratio finally adopts $1 / 9$, which ensures the vertical global stiffness and the slippery resistance factor between the main cable and saddle.

The global articulation is shown in Figure 2. Vertical bearings are installed at the bottom cross-beam of the side pylon; traverse wind bearings are installed on the inner side of all pylon shafts; longitudinal viscous dampers are installed on the side pylons; longitudinal cables are provided at the middle pylon cross-beam, which restrain the longitudinal displacement of main girder under traffic loading and earthquake loading. The approach bridge adopts a pre-stressed continuous box girder with a main span of $70 \mathrm{~m}$, which is not included in the paper.

\subsection{Pylon and foundation}

\subsubsection{Middle pylon and foundation}

Compared with the conventional double pylon suspension bridge, the triple-pylon suspension shows some different structural behaviours.

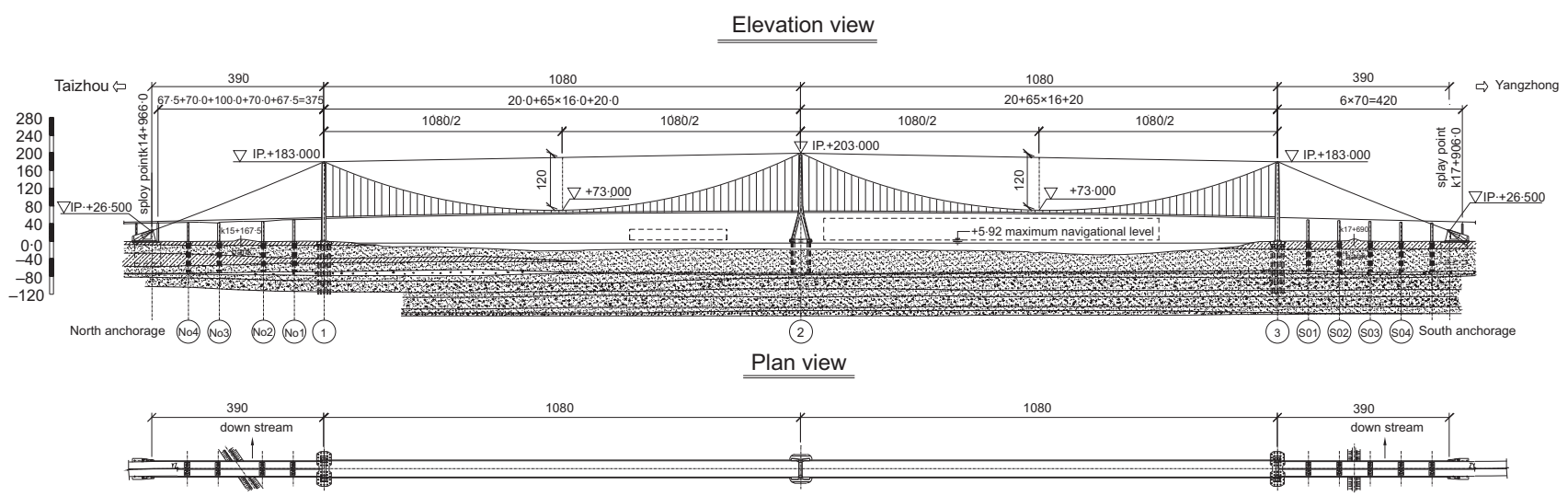

Figure 1. The general arrangement of the main bridge (unit: $\mathrm{m}$ ) 


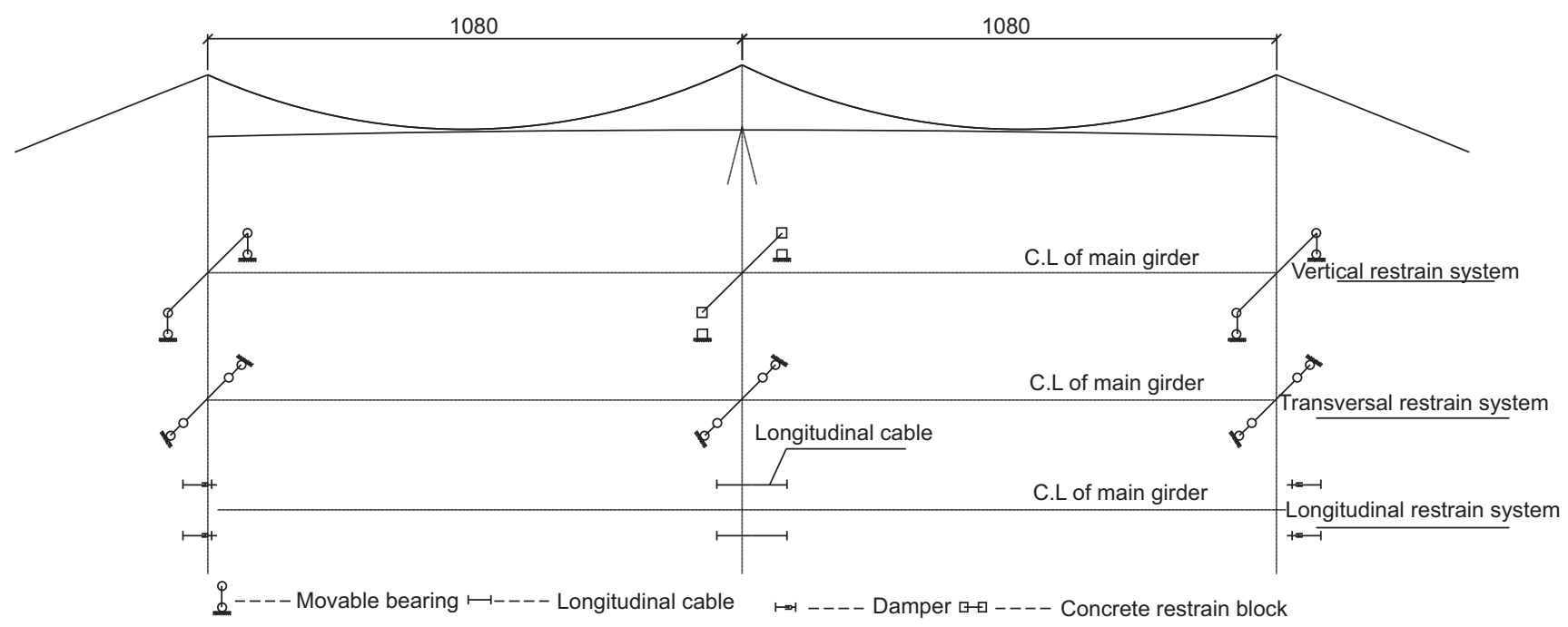

Figure 2. Global articulation of the bridge (unit: $\mathrm{m}$ )

(a) When one of the main spans is loaded by a full live load, but another main span is empty, the middle pylon should provide the restrain to the main cable, so the horizontal component of main cable force will change significantly.

(b) The main cable is anchored on the middle pylon; the longitudinal stiffness of the middle pylon is weaker than that of conventional double-pylon suspension bridge, in which the main cable is anchored on side anchorage, so the global vertical stiffness of the triple-pylon suspension bridge is weaker than the conventional double-pylon suspension bridge. In order to enhance the global vertical stiffness of the triple-pylon suspension bridge, the middle pylon often adopts a rigid or semi-rigid configuration, such as triangulation or inverted Y-type in the longitudinal direction. Therefore, the necessary longitudinal restraint of the pylon top is achieved by the large bending stiffness of triangulation or the inverted $\mathrm{Y}$ pylon structure. The solution can enhance the global vertical stiffness of the triple-pylon suspension bridge. The main disadvantage of applying triangular pylon structures is that this will induce a large longitudinal bending moment in the middle pylon shaft and foundation.

If the full rigid middle pylon is adopted, the scale of foundation will be very large because the bending moment under live load is very large. The horizontal difference of the main cable force of the middle pylon will be very large when one main span is fully loaded, and it will reduce the slippery resistance safety margin of the main cable on the saddle trough. Therefore a longitudinal semi-rigid steel pylon, with the inverted Y-type configuration in the longitudinal direction and transversely portal frame steel pylon, was designed for the middle pylon, as shown in Figure 3.
The semi-rigid middle pylon can ensure the global vertical stiffness of the bridge, and control the difference of the horizontal component of the main cable force, and ensure the slippery resistance between the main cable and middle saddle.

In the longitudinal direction, from the top to bottom, the middle pylon is divided into three sections: the upper linear shaft, the middle transition shaft and the bottom inclined pylon shaft. The middle transition segment is $25.775 \mathrm{~m}$ long. The pylon shafts are connected by two cross-beams. The crosssection of the upper pylon shaft is a single box with multiple cells and four corner chambers with a dimension of $0.6 \mathrm{~m} \times$ $0.6 \mathrm{~m}$ to reduce the vortex vibration forces of wind. The crosssection of the middle pylon shaft is shown in Figure 4.

The middle pylon uses grade Q370qD and Q420qD steel, which is required to a have yield strength of $370 \mathrm{MPa}$ and $420 \mathrm{MPa}$, respectively. Both $\mathrm{Q} 370 \mathrm{qD}$ and $\mathrm{Q} 420 \mathrm{qD}$ are required to have Charpy impact energy of $41 \mathrm{~J}$ at a temperature of $-20^{\circ} \mathrm{C}$. The transverse dimension of the cross-section of the pylon shaft remains $5.0 \mathrm{~m}$. The longitudinal dimension of the cross-section of the pylon shaft is variable.

The thickness of the flange and web of the pylon shaft varies from $50 \mathrm{~mm}$ to $60 \mathrm{~mm}$ and from $44 \mathrm{~mm}$ to $60 \mathrm{~mm}$, respectively. All stiffeners of the pylon adopt bulb cross-section, with thickness $40 \mathrm{~mm}$ and $48 \mathrm{~mm}$. The diaphragm spacing of the pylon shaft is $3 \mathrm{~m}$ or $2.5 \mathrm{~m}$. The ordinary diaphragm is $20 \mathrm{~mm}$ thick.

The pylon shaft was divided into 13 segments, $10.775 \mathrm{~m}$ to $20.000 \mathrm{~m}$ long. The segment $\mathrm{T} 0$, which connected with the concrete cap of the caisson and embedded in concrete, was the 


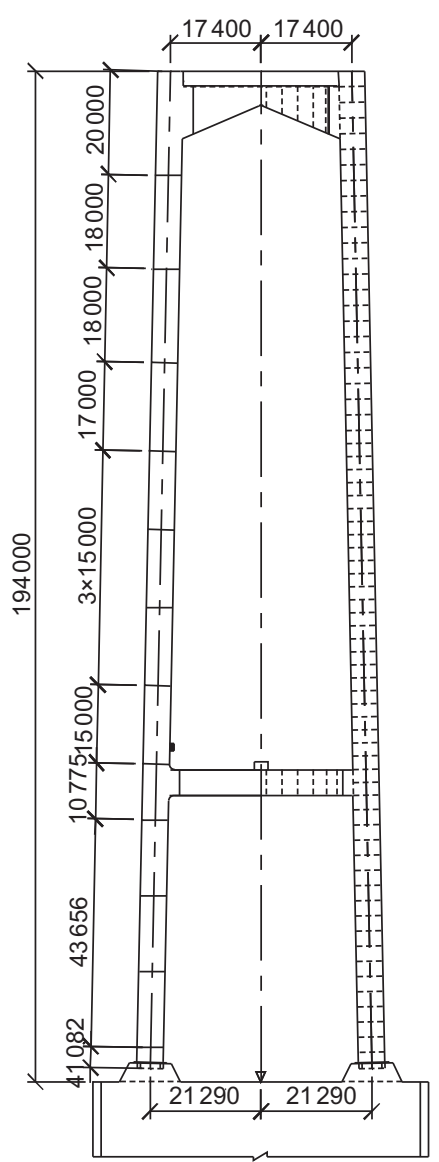

(a)
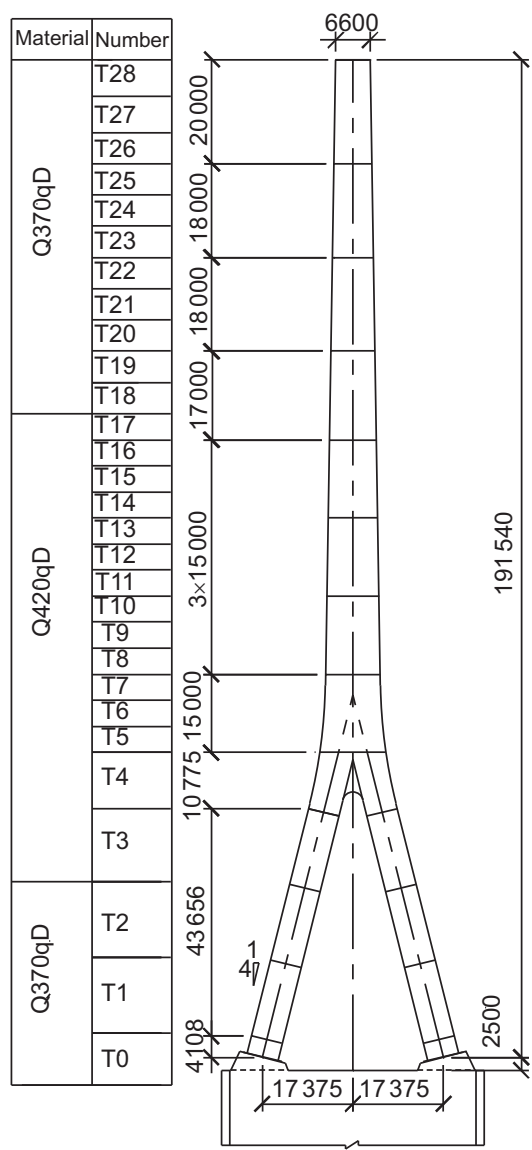

(b)

\begin{tabular}{|c|c|c|}
\hline Segment & Length: $\mathrm{m}$ & Weight: $\mathrm{t}$ \\
\hline D12 & $20 \cdot 000$ & $445 \cdot 1$ \\
\hline D11 & $18 \cdot 000$ & $327 \cdot 4$ \\
\hline D10 & $18 \cdot 000$ & $418 \cdot 4$ \\
\hline D9 & $17 \cdot 000$ & $412 \cdot 3$ \\
\hline D8 & $15 \cdot 000$ & $407 \cdot 0$ \\
\hline D7 & $15 \cdot 000$ & $426 \cdot 4$ \\
\hline D6 & $15 \cdot 000$ & $438 \cdot 5$ \\
\hline D5 & $15 \cdot 000$ & $495 \cdot 1$ \\
\hline D4 & $10 \cdot 775$ & $450 \cdot 8$ \\
\hline D3 & $15 \cdot 000$ & $255 \cdot 0$ \\
\hline D2 & $15 \cdot 000$ & $216 \cdot 4$ \\
\hline D1 & $15 \cdot 000$ & $216 \cdot 4$ \\
\hline D0 & $3 \cdot 485$ & $147 \cdot 2$ \\
\hline
\end{tabular}

Figure 3. General layout of middle pylon (unit: $\mathrm{mm}$ ): (a) front view; (b) side view; (c) segment length and weight
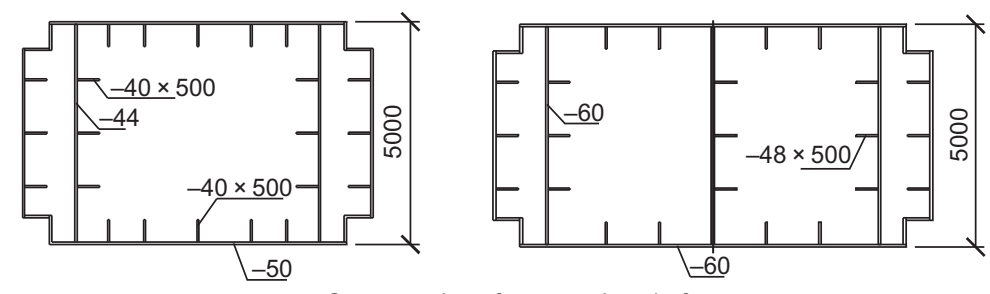

Cross-section of upper pylon shaft

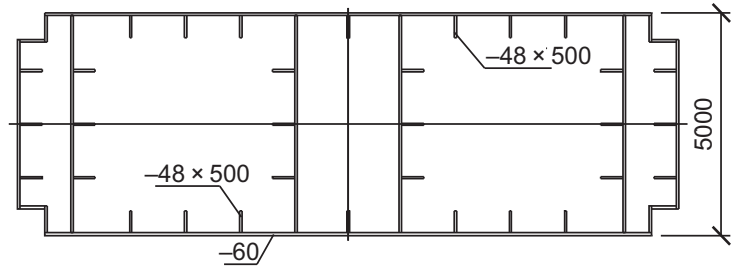

Cross-section of transition pylon shaft

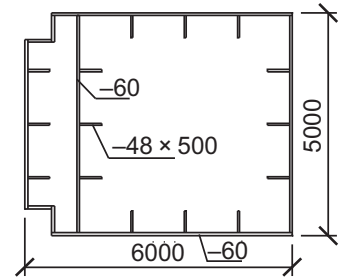

Cross-section of lower pylon shaft

Figure 4. The cross-section of middle pylon shaft (unit: $\mathrm{mm}$ ) 
exception. The site splices between the pylon shaft segments use high-strength bolts and the direct contact method. The ends of all segments were carefully milled so that $50 \%$ compression force was carried directly; the other $50 \%$ compression force, all tension force and shear force were carried directly by high-strength bolts.

The pylon shafts were fixed to the cap of the concrete caisson by anchorage bolts and bearing plates. A $150 \mathrm{~mm}$ thick bearing plate was welded to the pylon shaft bottom, so the compression force was transformed from the pylon shafts to the concrete bearing surface evenly. Large-diameter bolts were also utilised around the perimeter of the pylon shafts, as shown in Figure 5. The compression forces were transferred by the steel bearing plate, whereas the tension forces were transferred by highstrength bolts. The pre-tension force of the bolts was determined by zero tension stress at the pylon shaft bottom under the unfavourable load case. According to these principles, 34 no. of bolts with a diameter of $130 \mathrm{~mm}$ were used. The pre-tension force of each bolt was $3500 \mathrm{kN}$ under the construction stage. The total steel weight of the middle pylon was $13737 \cdot 1 \mathrm{t}$.

Alternatives of the caisson and bored pile foundation for the middle pylon were studied in the preliminary design stage. The material quantities and construction duration of caisson and bored pile foundation were listed in Table 1. According to Table 1, the caisson foundation was accepted by the client. The pile foundation consists of $118 \mathrm{no}$. friction piles of diameter $2.8 \mathrm{~m}$ and of $106.0 \mathrm{~m}$ depth; the rectangle caisson with chamber had a plan dimension of $58 \cdot 2 \mathrm{~m} \times 44 \cdot 1 \mathrm{~m}$ and a depth of $76 \cdot 00 \mathrm{~m}$.

According to the construction duration and the cost, the open suction caisson foundation was approved by the client. This was fitted with a cutting bottom edge facilitating sinking through sands by suction the sand in the honeycomb of large pipes. The open caisson used a rectangle cross-section with a plan dimension of $44 \mathrm{~m}$ and $60 \mathrm{~m}$ in the transverse and longitudinal direction, respectively. The total depth of the caisson was $76 \mathrm{~m}$, including $32 \mathrm{~m}$ concrete caisson and $44 \mathrm{~m}$ steel-shelled concrete caisson. The sub-sealing concrete was $8 \mathrm{~m}$ deep, as shown in Figure 6 . The total quantity of steel, concrete and reinforcement of the middle pylon caisson foundation was $4400 \mathrm{t}, 94934 \cdot 0 \mathrm{~m}^{3}$ and $3666 \cdot 4 \mathrm{t}$, respectively.

\subsubsection{Side pylon and foundation}

Both side pylons used a conventional reinforced concrete portal frame structure, and the foundation of the side pylons adopted a bored friction pile foundation. The pylon foundation at Taizhou side consisted of 46 no. piles with a diameter of

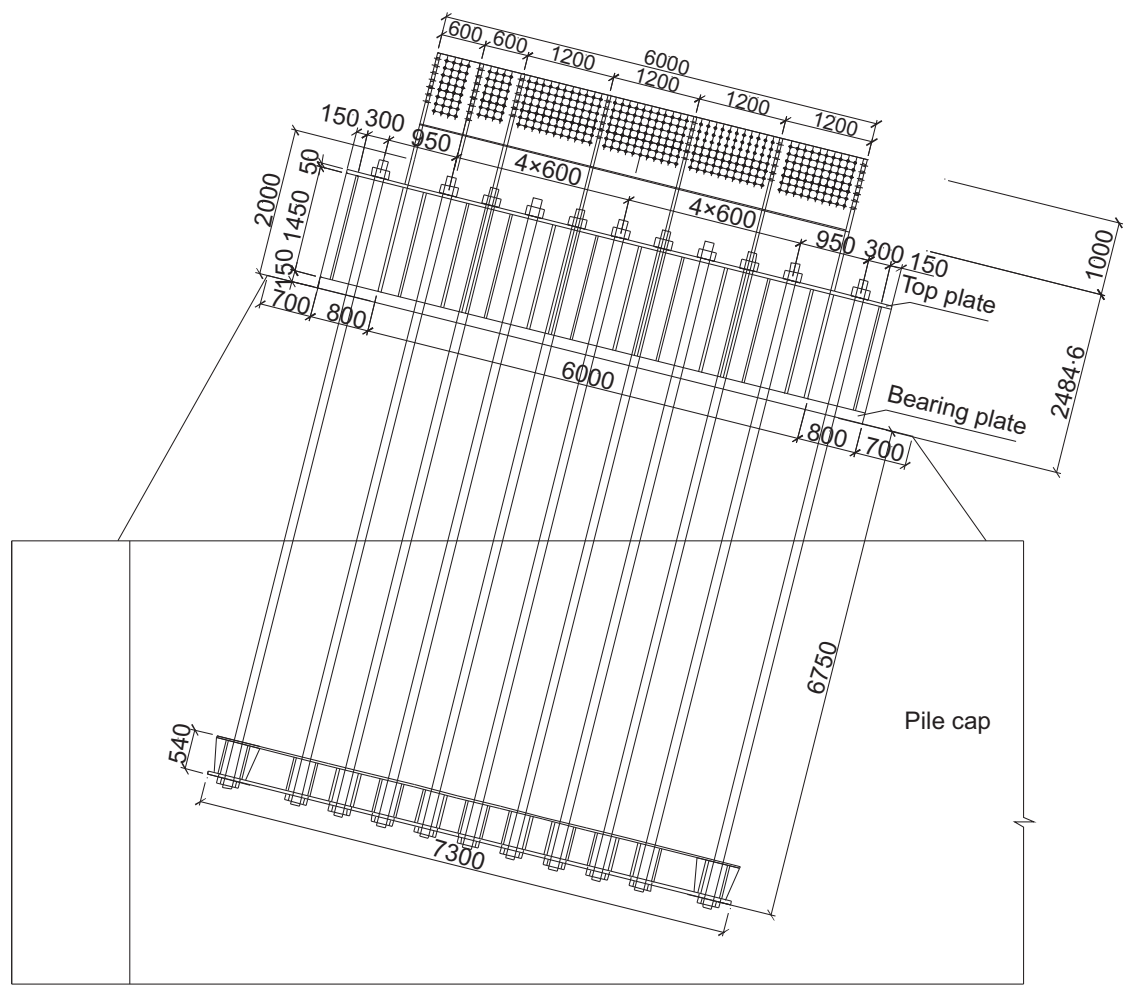

Figure 5. The connection between middle steel pylon shaft and concrete caisson cap (unit: $\mathrm{mm}$ ) 
Bill of quantities

Construction duration: month
Concrete: $\mathrm{m}^{3}$

Rebar: $\mathrm{t}$

Steel: $\mathrm{t}$

100725
3929
5376

5376
155972

23037

19880

27

Table 1. Bill of material quantities and construction duration of middle pylon foundation alternatives

$2.8 \mathrm{~m}$ and a depth of $103.00 \mathrm{~m}$, whereas the pylon foundation at the Yangzhong side consisted of 46 no. piles with a diameter of $2.8 \mathrm{~m}$ and a depth of $98.00 \mathrm{~m}$. Both side pylons were $175.7 \mathrm{~m}$ high. The concrete used for side pylon was required to have a minimum $50 \mathrm{MPa}$ cube compressive strength. The total concrete volume of each pylon was $13715 \cdot 6 \mathrm{~m}^{3}$.

\subsection{Anchorage}

Both anchorages, consisting of foundation and anchorage block, used gravity type owing to the poor geological condition. Both foundations used conventional concrete caisson, with a plan dimension of $44 \mathrm{~m}$ and $60 \mathrm{~m}$ in the transverse and longitudinal direction, respectively. The total depth of the caisson at the Taizhou and Yangzhong side was $57 \mathrm{~m}$ and $41 \mathrm{~m}$, respectively. Because both anchorages were located on the bank, only the bottom segment of the caisson adopted a steel-shelled concrete caisson, whereas the other segments adopted a reinforced concrete caisson. The construction method was similar to the middle pylon caisson foundation.

The anchorage block used a mass reinforced concrete structure and the front leg of the anchorage block adopted a box cross-section. The splay chamber was $24 \mathrm{~m}$ long, in which the main cable strands were scattered one by one, so each strand could be anchored with the concrete block. The main cable anchorage system was located in the concrete block with an anchorage length of $20 \mathrm{~m}$.

A dehumidification system was installed for the front anchor chamber and splay saddle chamber. Each dehumidification system comprised a dehumidifier, mixed pressure fan, connecting

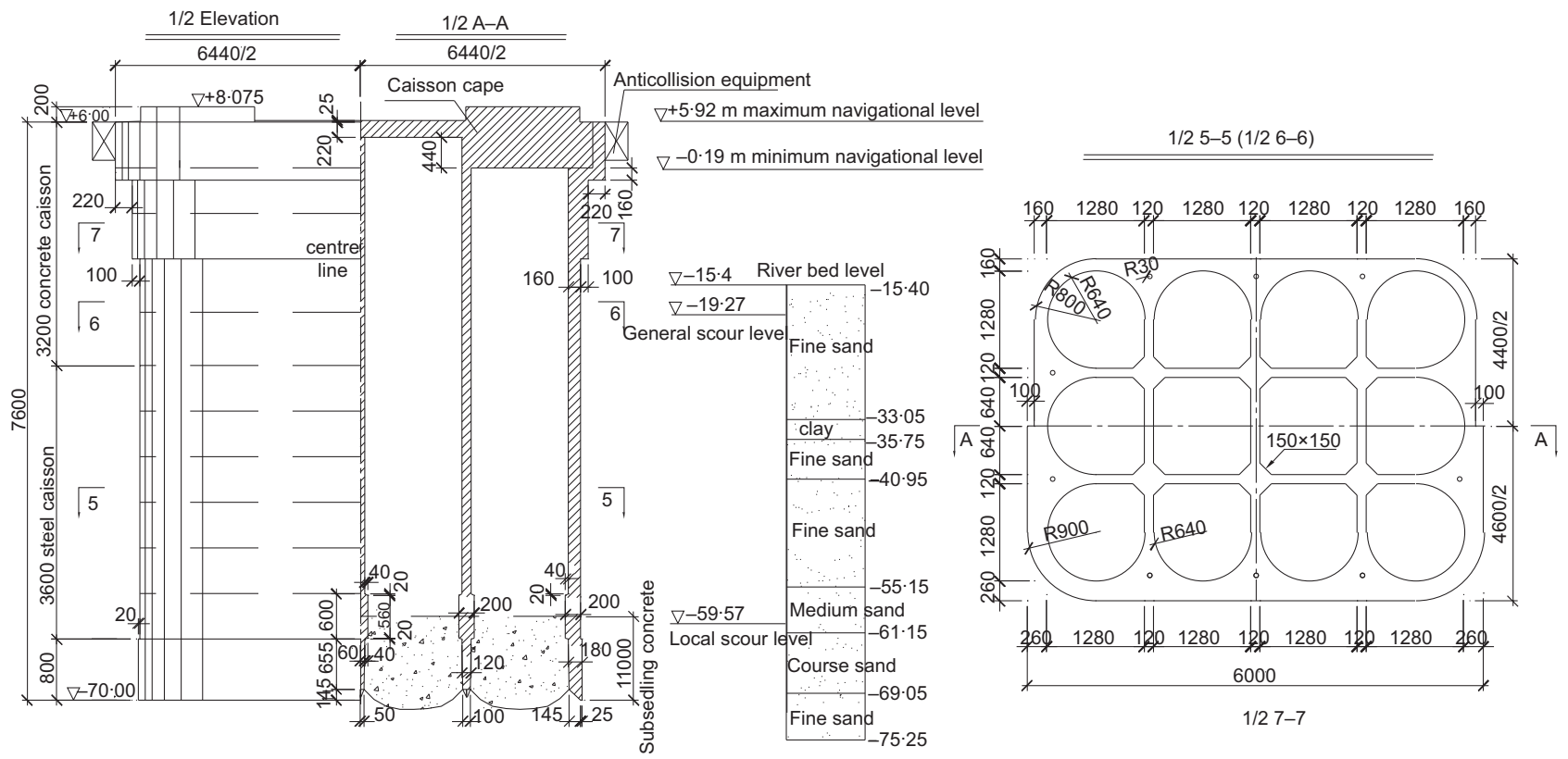

Figure 6. General layout of caisson foundation of middle pylon (unit: $\mathrm{cm}$ except level in $\mathrm{m}$ ) 
duct and electrical central control panel and humidity control devices. The force of the main cable strand was transferred to the concrete block by post-tension tendons.

\subsection{Steel box girder}

The steel box girder was $39.1 \mathrm{~m}$ wide and $3.5 \mathrm{~m}$ deep, adopting a flat streamlined box with good aerodynamic configuration (Figure 7). The double crossfall was $2 \%$. The double inner and outer inclined webs divided the steel box into three cells.

Allowing for the transportation capacity, the main girder was divided into 136 segments including 128 no. of standard segments and eight particular segments. The standard segment was $16.0 \mathrm{~m}$ long. The total weight of the standard segment was $215 \mathrm{t}$ and maximum weight of the segment was $230 \mathrm{t}$. The top plate and bottom plate thickness of the standard segment was $16 \mathrm{~mm}$ and $10 \mathrm{~mm}$, respectively.

In order to enhance the fatigue life of the steel orthotropic deck and improve the service performance of the deck pavement, the steel deck beneath the heavy carriageway in each direction was made of $16 \mathrm{~mm}$ thick plate and stiffened by $8 \mathrm{~mm}$ thick trapezoidal stiffener, whereas the rest of the steel deck plate was $14 \mathrm{~mm}$ thick and stiffened by $6 \mathrm{~mm}$ thick trapezoidal stiffener.

The bottom and top plate stiffener adopted a trapezoidal stiffener. The height and spacing of the top flange longitudinal stiffener were $280 \mathrm{~mm}$ and $600 \mathrm{~mm}$, respectively. The structural detail of the orthotropic deck including the dimensions of the top plate and longitudinal stiffener, minimum stiffness of longitudinal stiffeners, the connection of stiffener to deck plate and to the cross-beam, met all requirements of BS EN 1993-2 with the German national annex (Sedlacek et al., 2004).

The height, spacing and thickness of the bottom flange longitudinal stiffener were $250 \mathrm{~mm}, 1000 \mathrm{~mm}$ and $6 \mathrm{~mm}$ respectively. The spacing of the cross beams was $3 \cdot 2 \mathrm{~m}$. Both inclined top and bottom webs were $10 \mathrm{~mm}$ thick with flat stiffeners. The maintenance walk was located on the cantilever.

The site splices of the steel box girder were welded. The total weight of the steel box girder was $33681.9 \mathrm{t}$ with unit weight of $414 \mathrm{~kg} / \mathrm{m}^{2}$. The grade Q345qD was adopted for the steel box girder, which was required to have a yield strength of $345 \mathrm{MPa}$. The grade Q370qD was adopted for the hanger connection with the steel box girder anchorage, which was required to have a yield strength of $370 \mathrm{MPa}$. Both Q345qD and Q370qD were required to have $41 \mathrm{~J}$ impact test energy at a temperature of $-20^{\circ} \mathrm{C}$.

The steel orthotropic deck system was analysed by the PeklianEsslinger method (Wolchuk, 1963). The stresses of the deck system are presented in Table 2.

The hanger was connected with the box girder by a pin. The local stresses of anchorage zone were analysed by the finiteelement model.

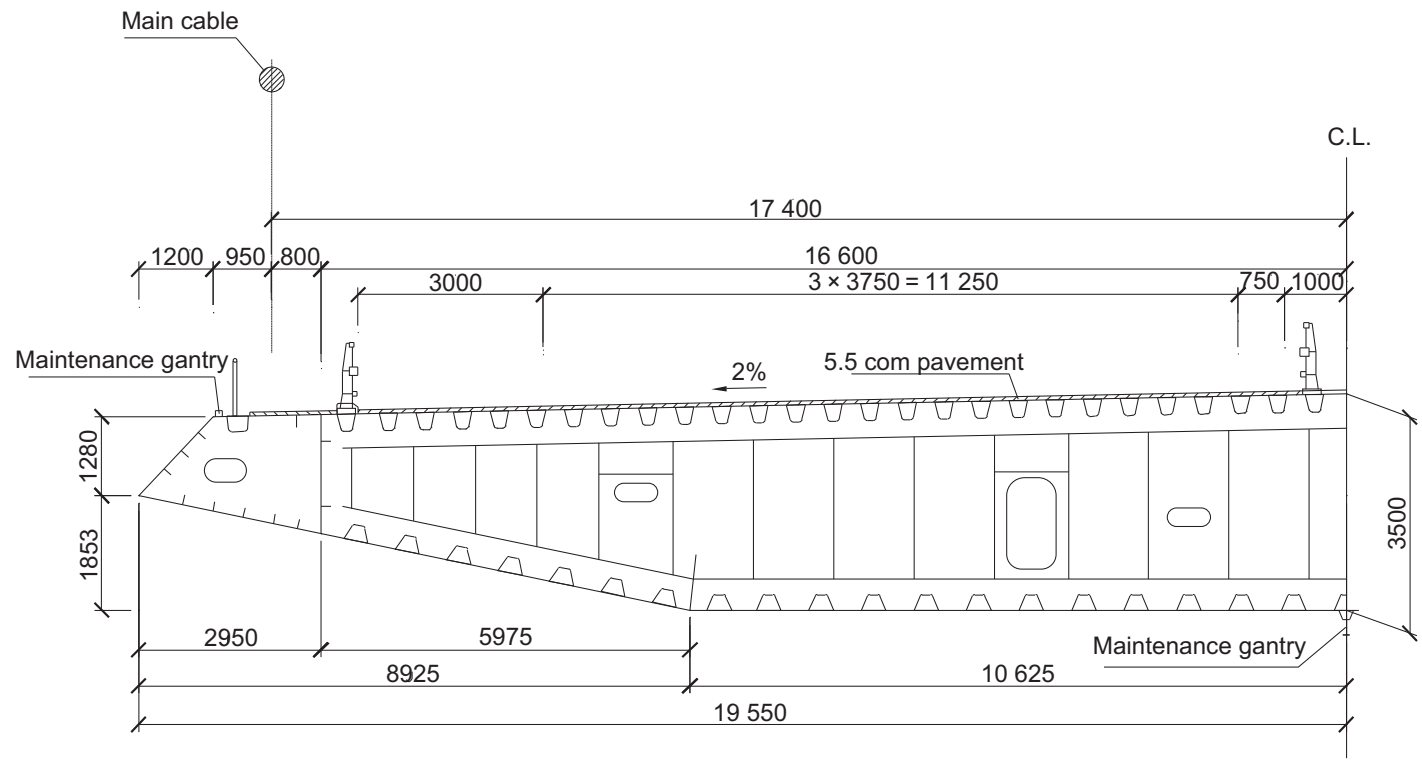

Figure 7. Typical cross-section of standard segment of steel box girder (unit: $\mathrm{mm}$ ) 


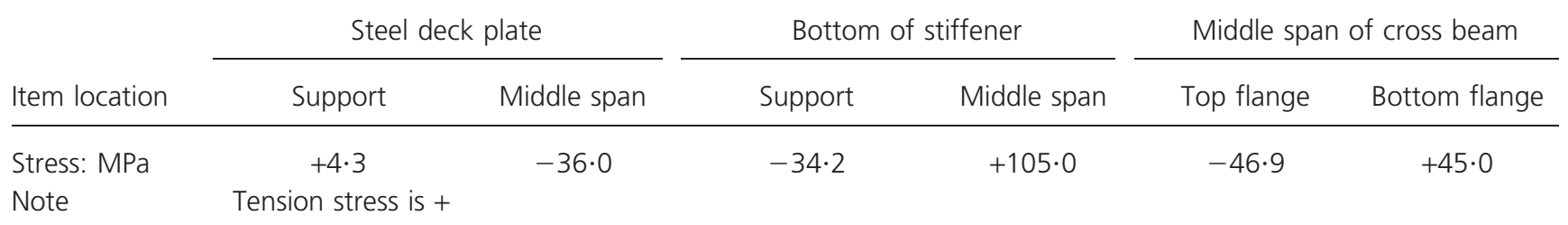

Table 2. Stresses of steel orthotropic deck

\subsection{Main cable, hanger and cable band}

The main bridge had two main cables, which used prefabricated parallel wire strand (PPWS). Each strand consisted of 91 no. of steel wire with a diameter of $5.20 \mathrm{~mm}$ and a minimum ultimate tensile strength of $1670 \mathrm{MPa}$. Each main cable had 169 steel strands. The length and weight of each strand was approximately $3100 \mathrm{~m}$ and $47 \mathrm{t}$, respectively. The main cables were protected with S-wire wrapping and a cable dehumidification protection system.

The S-wire consisted of 'flat', interlocking wire for the outer transverse wrapping of main cables. The S-wire wrapping had a S-shaped cross-section of $7 \times 3.0 \mathrm{~mm}$ (Figure 8 ), and was wrapped around a cable in a spiral format. The interlocking mechanism of the S-wire minimised the gaps between successive loops of the wrapping wire. Therefore this method could minimise the amount of moisture penetrating into the cable after construction.

The cross-section area of the main cable was $0.3266 \mathrm{~m}^{2}$. The main spacing ratio, based on both home and abroad long-span suspension bridges, was $18 \%$ at the cable band and $20 \%$ elsewhere; the associated diameter of the main cable was $712 \mathrm{~mm}$ and $721 \mathrm{~mm}$, respectively.

All hangers were considered for the hanger replacement load case. The objective of hanger replacement is to satisfy the client that any such future scenario could be undertaken under sustainable conditions involving limited traffic disruption and without the need for full closures. The total weight of the main cable, hanger was $15929 \mathrm{t}$ and $447 \cdot 2 \mathrm{t}$, respectively.

The hanger used a prefabricated parallel wire strand, which included two types: (a) the particular hanger, located adjacent to the centre pylon with three prefabricated parallel wire strands and (b) the common hangers, located at the other locations, with double parallel wire strands. Each prefabricated parallel wire strand consisted of 87 no. of steel wires with a diameter of $5.20 \mathrm{~mm}$. The minimum ultimate tensile strength of hanger steel wire was $1670 \mathrm{MPa}$.

The hanger connected with the steel box girder and cable band through fork plate and pin. The cable band consisted of upper and lower mating pairs, and the two halves were connected with high-strength waisted bolts to avoid the bolt breaking at the thread. The two halves were sealed with waterproof rubber strips. The cable band were made of ZG20SiMn cast steel, with wall thickness varying from $35 \mathrm{~mm}$ to $45 \mathrm{~mm}$. The configuration of hanger and cable band are shown in Figure 9.

\subsection{Main saddle and splay saddle}

The main saddle and splay saddle were made of cast and welded steel structure. The head of the saddle was made of cast

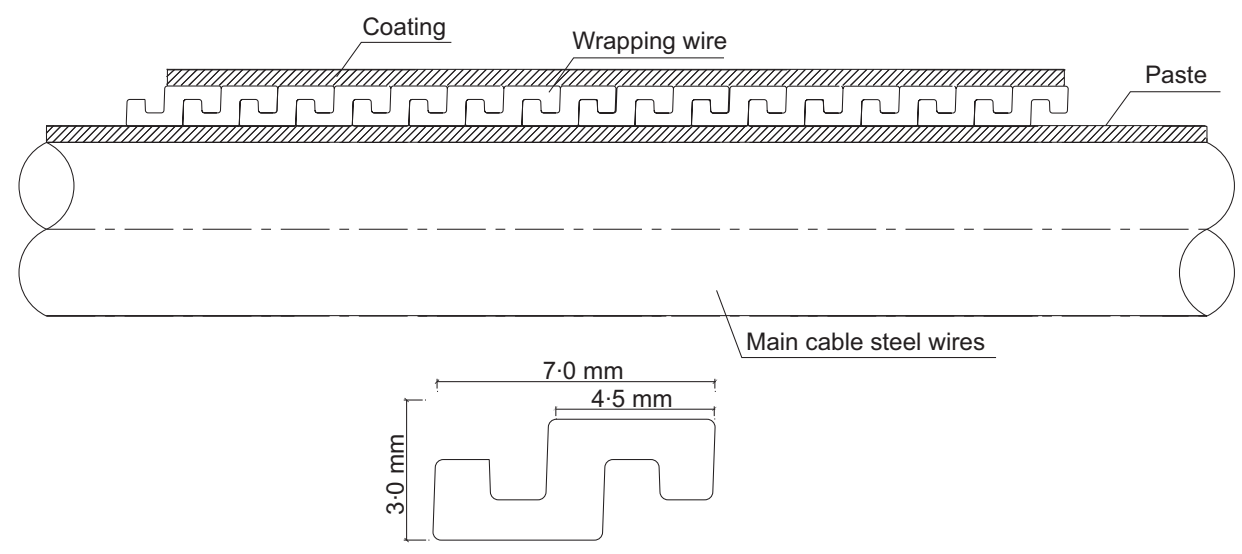

Figure 8. Interlocking wrapping S-wire (unit: $\mathrm{mm}$ ) 


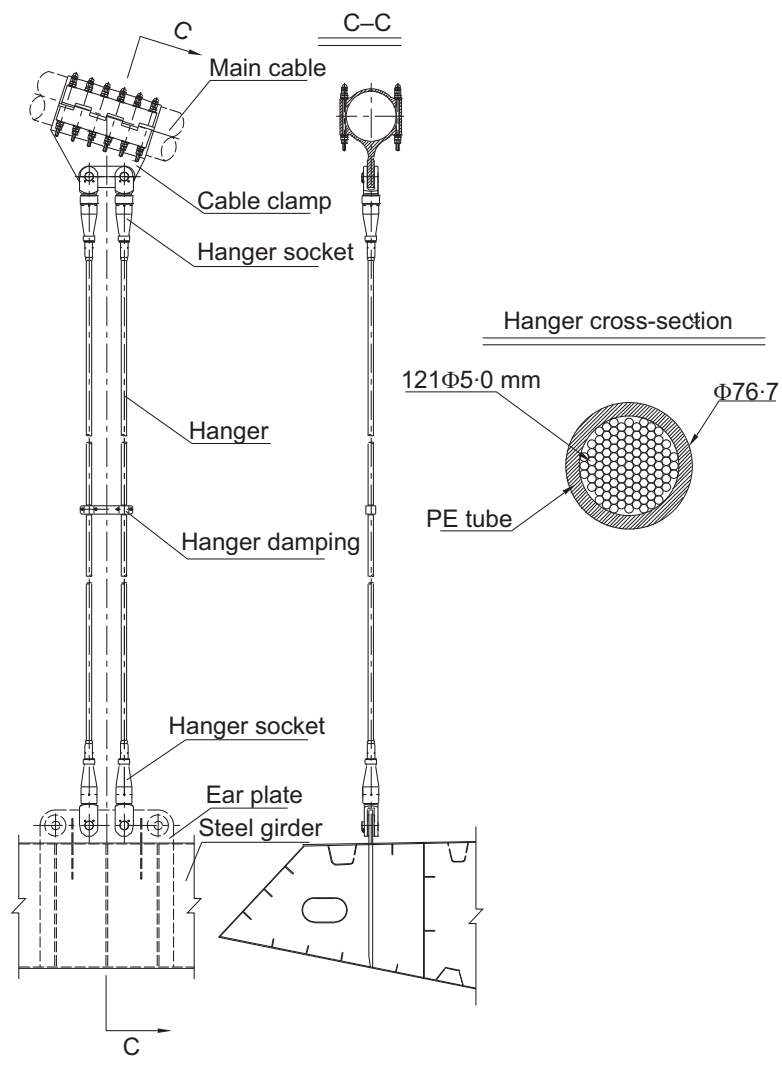

Figure 9. Configuration of hanger steel owing to the complex configuration, and the body of saddle was made of welded steel plates. A stainless sliding plate was embedded on the pylon head, to provide sliding during the cable and steel box girder installation stages.

To facilitate the fabrication and installation of the main saddle, it was divided into two parts in the longitudinal direction, which were fabricated and installed separately. The site splice was connected by high-strength bolts, as shown in Figure 10. In order to increase the friction force between the main cable strands and saddle trough, vertical plates were provided to form channels in the saddle. After installation and adjustment of the main cable, the gaps between the plates were filled with zinc blocks, and then the side wall of the saddle trough was compressed against the cable through high-strength bolts. The weight of the middle pylon and side pylon saddle was about $94.8 \mathrm{t}$ and $132.8 \mathrm{t}$, respectively.

The splay saddle used a hinge at the bottom so it could rotate around the hinge. The head trough was made of cast steel, and the saddle body was made of welded steel plates. The weight of the splay saddle was $102 \cdot 7 \mathrm{t}$.

\section{Global static analysis}

\subsection{Global static analysis}

A three-dimensional non-linear finite-element model was adopted in the global static and dynamic analysis. The pylon and steel box girder were modelled as six-degree freedom beam

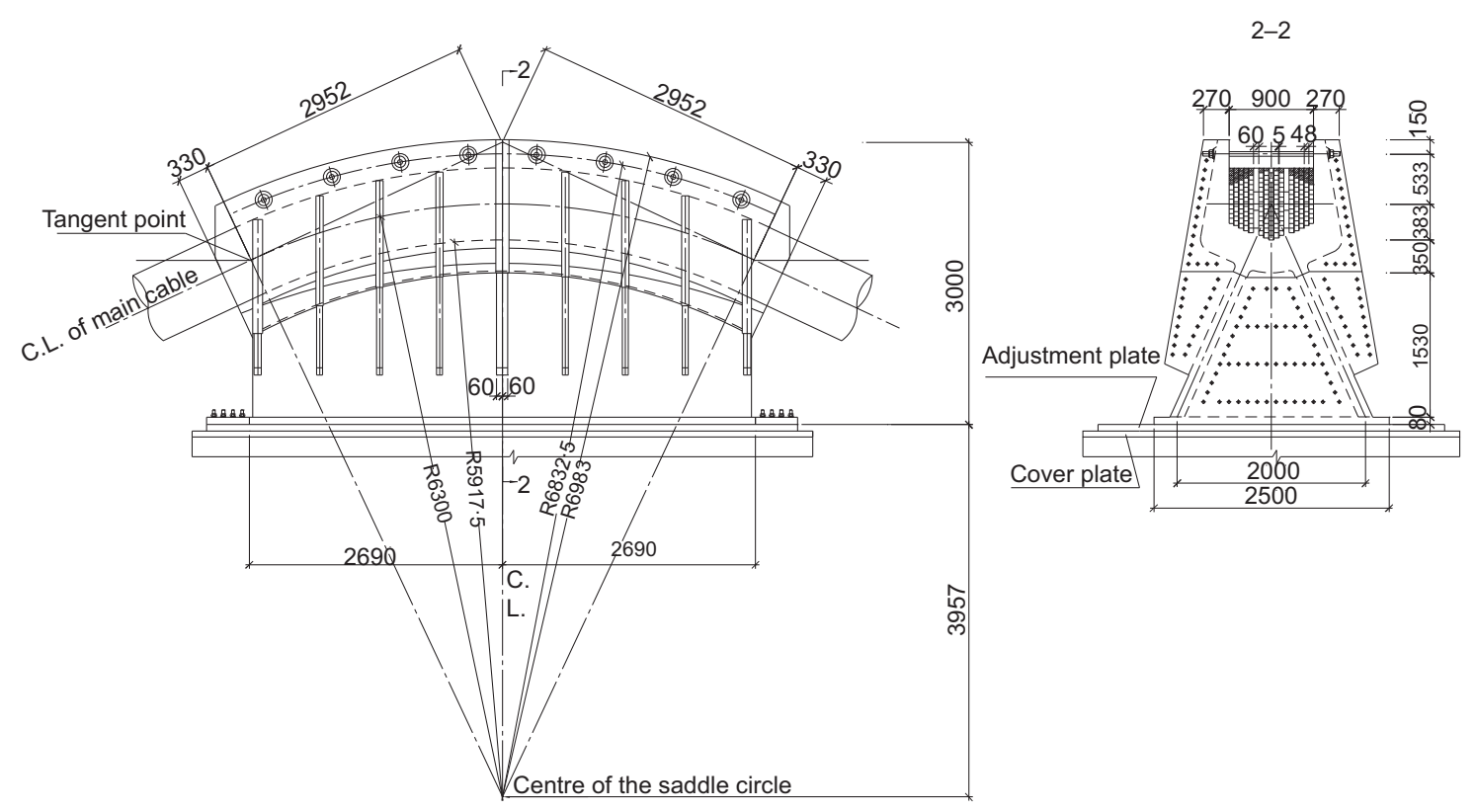

Figure 10. General configuration of main saddle on middle pylon (unit: $\mathrm{mm}$ ) 
elements, and the main cable and hanger were modelled as three-degree freedom bar elements. The traffic live load adopted eight lanes of Chinese highway bridge design load. The design live load included a uniformly distributed load and a concentrate load. The magnitude of the uniformly distributed load and concentrate load was $39.06 \mathrm{kN} / \mathrm{m}$ and $1339 \mathrm{kN}$, respectively.

The bending moment of steel box girder under traffic load is shown in Figure 11. As shown in Figure 11, the maximum vertical deflection was $4.37 \mathrm{~m}$. The ratio of maximum deflection to main span was $1 / 253 \cdot 5$, which indicated that the bridge was rigid. The limitation of the ratio of maximum deflection to main span in CSHSB was $1 / 250$.

With the combination of dead load, traffic load and the lower temperature, the maximum main cable force was $210909 \mathrm{kN}$, which was located at both sides of the middle pylon. CSHSB adopted an allowable stress method; the cable-related safety factor was 2.5 and 3.0 for the hanger. The factor for the main cable adopted in BS EN 1993-1-11 (CEN, 2006) was about 2.2, which took into consideration the live load and dead load with the combination factor of about $1 \cdot 35$ to $1 \cdot 45$. This was about $15 \%$ smaller than the Chinese code. The safety factor of main cable according to CSHSB is shown in Table 3.

\subsection{Slip resistance stability of the main cable on the middle pylon saddle}

The friction factor between the middle pylon cable saddle groove and the main cable is not described in the Chinese bridge design code and BS EN 1993-1-11 (CEN, 2006). In order to ensure the safety of the bridge, the friction factor was tested by Southwest Jiaotong University, China. The test included two groups, each group included three specimens.
One group was tested by 10 strands, and the other group was tested by a single strand. A photograph of 10 strands is shown in Figure 12.

The three specimens of the 10 strands test result are $0 \cdot 521,0.535$ and 0.535 , respectively. The three specimens of single strand test result are $0 \cdot 302,0 \cdot 326$ and $0 \cdot 391$, respectively. The friction factor tested by multiple strands was much bigger than those of the single strand because the top strands compress the bottom strands. The bridge was the first triple-pylon suspension bridge with a main span larger than $1000 \mathrm{~m}$. The coefficient adopted in the design was $0 \cdot 2$. So the slipping resistance factor of the main cable strands on the middle pylon saddle was calculated by the Euler-Eytelwein formula (Gross et al., 2009)

$$
K=\frac{\mu \times \alpha_{\mathrm{s}}}{\ln \left(\frac{F_{\mathrm{Ed} 1}}{F_{\mathrm{Ed} 2}}\right)}=\frac{0 \cdot 20 \times 0 \cdot 871}{\ln \left(\frac{202232 \cdot 6}{190325 \cdot 8}\right)}=2 \cdot 897
$$

In which $F_{\mathrm{Ed} 1}$ and $F_{\mathrm{Ed} 2}$ are the design values of the maximum and minimum cable force on either side of the middle pylon; $\mu$ is the frictional factor between main cable and saddle trough; $\alpha_{\mathrm{S}}$ is the angle in radians of the cable passing over the main saddle, $\alpha_{\mathrm{s}}=2 \times 25.1833^{\circ}=0.879 \mathrm{rad}$. The minimum slipping resistance factor $K$ in CSHSB and BS EN 1993-1-11 was 2.0 and $1 \cdot 65$, respectively. As shown in the preceding formula, the minimum slipping resistance factor $K$ met the requirement of CSHSB and BS EN 1993-1-11 (CEN, 2006).

\section{Construction introduction of the main bridge}

The side pylons were located on the bank, so the pile foundation was constructed with a rotated bored machine

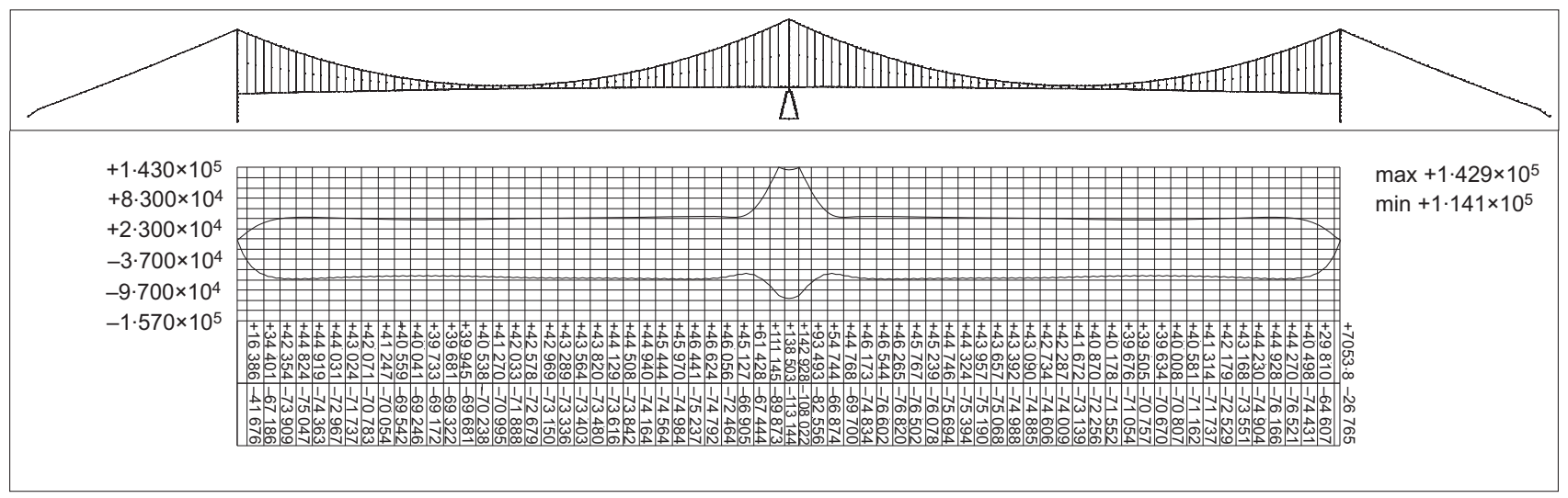

Figure 11. The bending moment of steel girder under traffic load unit ( $\mathrm{kN} \mathrm{m}$ ) 


\begin{tabular}{|c|c|c|c|c|c|c|c|c|c|c|}
\hline Location and item & (1) & $(2)$ & (3) & (4) & (5) & (6) & (7) & (8) & (9) & (10) \\
\hline Axial force: kN & 203846 & 207872 & 207889 & 191027 & 210909 & 210909 & 191027 & 207889 & 207872 & 203846 \\
\hline Safety factor & $2 \cdot 68$ & $2 \cdot 62$ & $2 \cdot 62$ & $2 \cdot 86$ & $2 \cdot 59$ & $2 \cdot 59$ & $2 \cdot 86$ & $2 \cdot 62$ & $2 \cdot 62$ & $2 \cdot 68$ \\
\hline
\end{tabular}

Table 3. Safety factor of main cable

directly with slurry. The steel shell caisson of the middle pylon foundation was fabricated in the workshop, transported to the site, and installed by a floating crane. The concrete was then cast in situ between the double wall of steel shells. A water-jet was used to wash the soil of the riverbed, so the caisson could penetrate in the sand by its self-weight (Figure 13). The depth of the caisson was extended segment by segment and then sunk down under the water step by step, until the caisson reached its design level. Then the bottom was sealed with concrete deposited underwater. Then the concrete filling was casted under water.

The concrete was supplied from both river banks. Two batch concrete plants were set up on both sides. The side pylon was constructed by a hydraulic self-climbing formwork in which a typical segment was $6 \mathrm{~m}$ long, and an ordinary cycle was achieved in 7 days.

The segments $\mathrm{T} 0$ to $\mathrm{T} 7$ and $\mathrm{T} 8$ to $\mathrm{T} 28$ of middle pylon were constructed by a floating crane and pylon crane, respectively. The longitudinal and transverse segments must be perpendicular to within an allowance of 1/10 000 .

The main cable was constructed by a catwalk and traction system. The catwalk system consists upstream catwalk, downstream catwalk and several transverse path walk. The catwalk

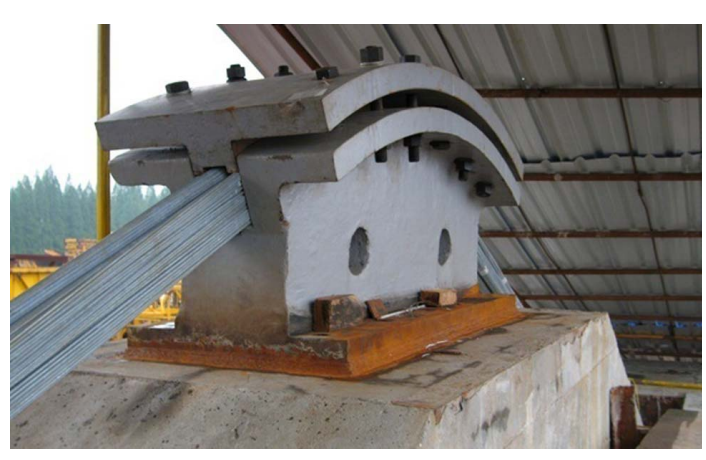

Figure 12. Slipping resistance test was located beneath the associated main cable, and the cable strand traction system adopted a double-way system. The sag of each cable strand was adjusted between 0 and $3 \mathrm{am}$ in the morning, because the temperature is very steady in this period.

The erection sequence of steel box girder was installed from the middle of the double middle span to the middle pylon and side pylons symmetrically. Two enclosure segments were set near the side pylons and middle pylon, respectively. Four main cable-supported cranes were used for the installation of the segments of the steel box girder, which can crawl along the middle span main cables. For each segment erection and site welding, the quickest cycle was achieved in 7 days. The Taizhou and Yangzhong side pylon main saddle was preset with a longitudinal deviation distance of $2.465 \mathrm{~m}$ and $2.410 \mathrm{~m}$ towards the bank, respectively. The splay saddle of Taizhou and Yangzhong side were also preset with an angle of $0.0591^{\circ}$ and $0.0562^{\circ}$ towards the bank, respectively.

The cable and deck construction was continuously monitored by the on-site technical team to ensure that the required final design vertical and horizontal profiles were achieved. The segment erection level was continuously adjusted to take into account the difference between theoretical analysis deflection and site measurements.

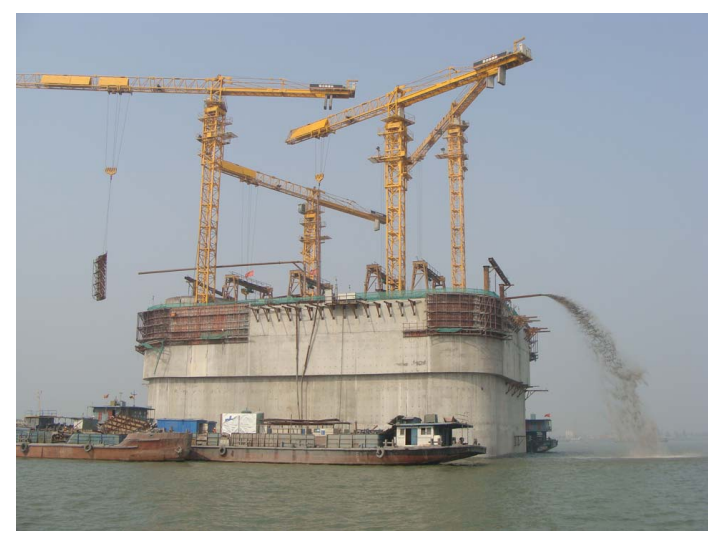

Figure 13. Caisson sunk by suction of the sand and soft clay 


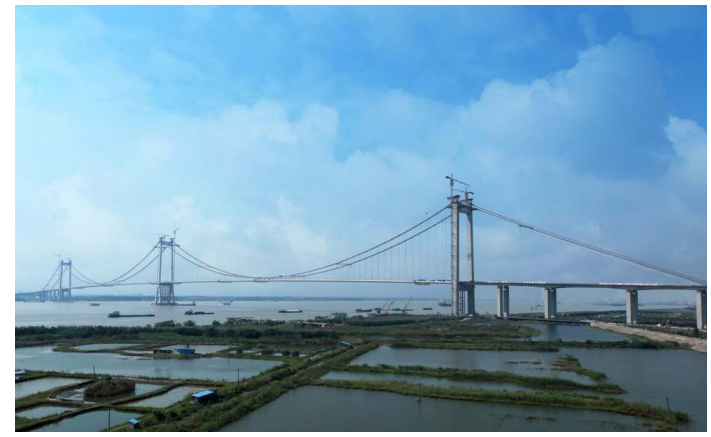

Figure 14. Photograph of nearly completed main bridge

The construction of the bridge commenced on 26 December 2007. The construction duration of the middle pylon foundation and pylon shaft was 15 months and 14 months, respectively. The construction duration of main cable and steel box girder erection wass 4 months and 8 months, respectively.

\section{Conclusions}

The bridge was opened to traffic on 25 November 2012. The nearly completed bridge is shown in Figure 14. The design and construction of the bridge were completed on time and on budget as a result of the excellent cooperation between the client, designer, contractors, sub-contractors and site supervision consultants.

The fast progress of the construction of the project benefited from a viable design concept and solutions, which changed very little during the construction. The considerable investment made by the contractor in additional ground investigation and scientific research and test enabled the development of a safe and efficient substructure and superstructure design.
The bridge has been well recognised by Jiangsu Province government and Ministry of Communication of China, who regard the construction of the first major triple-pylon largespan suspension bridge in the world as a symbol of bridge technology progress.

\section{Acknowledgements}

The authors would like to acknowledge the help of Mr Jin Yang, Chinese National Design Master, and Jianhchi Zhong, the site director of Jiangsu Provincial Yangtze River Highway Bridge Construction Commanding Department, and colleagues of the design teams, independent checking teams and construction teams and site construction supervision teams.

\section{REFERENCES}

CEN (Comité Europé en de Normalisation) (2005) EN 1993-2:

Eurocode 3: Design of steel structures. Part 2: Steel bridges. Comité Europé en de Normalisation, Brussels, Belgium.

CEN (2006) EN 1993-1-11: Eurocode 3: Design of steel structures. Part 1-11: Design of structures with tension components. Comité Europé en de Normalisation, Brussels, Belgium.

DIN (2003) Fachbericht 103. Stahlbrücken. Deutsches Instituft für Normung, Beuth Verlag, Berlin, Germany (in German).

Gross D, Werner Hauger W, Schröder J et al. (2012) Engineering Mechanics 1: Statics. Springer, Berlin.

Sedlacek G, Eisel H, Kühn W and Paschen B (2004) Leitfaden zum DIN Fachbericht 103 Stahlbrücken (March, 2003). Ernst \& Sohn.

Wolchuk R (1963) Design Manual for Orthotropic Steel Plate Deck Bridges. American Institute of Steel Construction, Chicago, IL, USA.

\section{WHAT DO YOU THINK?}

To discuss this paper, please email up to 500 words to the editor at journals@ice.org.uk. Your contribution will be forwarded to the author(s) for a reply and, if considered appropriate by the editorial panel, will be published as discussion in a future issue of the journal.

Proceedings journals rely entirely on contributions sent in by civil engineering professionals, academics and students. Papers should be 2000-5000 words long (briefing papers should be 1000-2000 words long), with adequate illustrations and references. You can submit your paper online via www.icevirtuallibrary.com/content/journals, where you will also find detailed author guidelines. 